\title{
KOJŲ RAUMENŲ ADAPTACIJA TAIKANT SKIRTINGŲ STRATEGIJŲ JÉGOS KRŪVIUS
}

\author{
Sigitas Kamandulis ${ }^{1}$, Albertas Skurvydas ${ }^{1}$, Marius Brazaitis ${ }^{1}$, Daiva Imbrasiene $\dot{e}^{1,2}$, \\ Nerijus Masiulis ${ }^{1}$, Zita Andrijauskaité ${ }^{1}$, Audrius Sniečkus ${ }^{1}$, Vidas Paleckis ${ }^{1}$, Darius Babickas ${ }^{3}$ \\ Lietuvos kūno kultūros akademija ${ }^{1}$, Kauno medicinos universitetas ${ }^{2}$, Sporto klubas „,Ideja “3 , Kaunas, Lietuva
}

Sigitas Kamandulis. Biomedicinos mokslų daktaras, Lietuvos kūno kultūros akademijos Sportinių žaidimu katedroje einantis docento pareigas, Sporto ir judesių mokslo centro vyresnysis mokslo darbuotojas. Mokslinių tyrimų kryptis — žmogaus motorinės sistemos adaptacija prie fizinio krūvio, sukeliančio raumenų pažeidą.

\begin{abstract}
SANTRAUKA
Küno rengybos specialistai dažnai taiko 10 seriju metodika (viena raumenu grupe treniruojama tiktai karta per savaite atliekant vienq pratima 10 seriju po 10 kartojimu), tačiau šios metodikos veiksmingumas moksliniais eksperimentais mažai pagristas. Taigi tyrimo tikslas — nustatyti keturgalvio šlaunies raumens storio ir koju raumenu jejgos pokyti po septyniu savaičiu trukmés pratybu, atliktu taikant skirtingas jëgos lavinimo metodikas. Buvo kelta hipotezè, kad dažni mažos apimties jègos ugdymo krūviai yra veiksmingesni nei reti didelès apimties. Pastarieji, būdami ne tokie intensyvūs, mažiau aktyvuoja nervinius ir hormoninius mechanizmus, nио kuriu ypač priklauso raumenu jëgos ir masès didèjimas.
\end{abstract}

Buvo tiriama 14 fiziškai aktyviu vyru, kuriu amžius - 23,3 $\pm 5,2 \mathrm{~m}$., ügis $-181,7 \pm 5,1 \mathrm{~cm}$, svoris $-77,7 \pm 11,1 \mathrm{~kg}$. Prieš eksperimenta tiriamieji treniruokliu atliko spaudimo kojomis testa, po kurio pagal gautus rezultatus buvo suskirstyti i dvi grupes: pirmq eksperimentine (E 1 - atliko dažnus, mažos apimties krüvius) ir antra eksperimentine (E 2 - atliko retus didelès apimties krüvius). Eksperimentas truko 7 savaites. Kiekvienq savaitę tiriamieji turëjo po trejas pratybas. Abi eksperimentinès grupès vienodai treniravo visus kūno, išskyrus koju raumenis. E 1 tiriamieji treniruokliu spaudè svori kojomis 3 kartus per savaite po 3, 3 ir 4 serijas po 10 kartojimu. E 2 tiriamieji spaudè svori kojomis vienq kartq per savaitę 10 seriju po 10 kartojimu. Matuoti rodikliai prieš eksperimentq ir po jo: keturgalvio šlaunies raumens storis (ultragarsu), izometrinè maksimalioji valinga ir $100 \mathrm{~Hz}$ elektrostimuliacijos sukelta jèga, per kelio sqnarì esant $70^{\circ}$ kampui $\left(0^{\circ}\right.$ — koja visiškai ištiesta), izokinetiné koncentrinè jèga - $30^{\circ} / \mathrm{s}$ ir $300^{\circ} / \mathrm{s}$ greičiu, maksimalioji koju raumenujèga — spaudžiant svorį treniruokliu, kūno svoris, riebalu procentas, apskaičiuotas kūno masès indeksas.

Po septyniq savaičciu jègos krūviu E 1 grupès tiriamuju keturgalvio šlaunies raumens storis padidèjo 10,6 \pm 9,5\% $(p<0,05), E 2-12,6 \pm 11,3 \%(p<0,05)(p>0,05$, lyginant $E 1$ ir $E 2$ rodiklius). Eksperimento metu labiausiai padidejo maksimalioji koju raumenujejga spaudžiant svori treniruokliu: $17,7 \pm 11,2 \%(p<0,05)$ E 1 ir 19,2 $\pm 12,3 \%$ $(p<0,05)$ E 2 grupeje ( $p>0,05$, lyginant $E 1$ ir E 2 rodiklius). Tuo tarpu izometrine maksimalioji valinga ir $100 \mathrm{~Hz}$ elektrostimuliacijos sukelta jèga bei izokinetinès koncentrinès jègos momentas statistiškai reikšmingai nepasikeite ir nepriklausè nuo taikytos krūviu išdèstymo strategijos.

Tyrimo rezultatai parodè, kad motorinès sistemos adaptacija yra labai specifinè. Reti didelès apimties ir dažni mažos apimties septyniu savaiči trukmès raumenu jègos lavinimo krūviai labai padidino keturgalvio šlaunies raumens stori ir maksimaliaja koju raumenu jègq spaudžiant svorị treniruokliu, tačiau mažai keitè izometrinę bei izokinetine jèga. Taikant skirtinga jejgos ugdymo metodika, aktyvuojami ne tie patys adaptacijos mechanizmai, tačian buvo sukeltas labai panašus adaptacijos efektas.

Raktažodžiai: 10 seriju metodas, keturgalvio šlaunies raumens storis, izometrine jëga, izokinetinè jèga, elektrostimuliacija.

\section{IVADAS}

$\mathrm{V}$ aržybų rezultatai pasiekiami nuolat didinant funkcines organizmo galimybes (Bompa, 1999). Vienas iš svarbiausiu veiksnių, lemiančiu sportininko pasirengimo lygi, yra griaučių raumenu jèga. Taikant jègos lavinimo krūvị, raumeninèse skaidulose padidèja baltymų sintezè. Šiam procesui būdinga: 1) metabolitų su- sikaupimas; 2) nuo insulino priklausančio augimo veiksnio (IGF-1), testosterono ir kitu raumenu augimą skatinančių hormonų sekrecija; 3) raumenų pažeida ir padidèjęs genų, reguliuojančių baltymų sintezę, bei satelitinių ląstelių aktyvumas (Jennische et al., 1987; Häkkinen, 1989; Jones et al., 1989; Tesch, Alkner, 2003; Crewther et al., 
2006). Raumenų susitraukimo jèga didejja ir dèl centrinių nervinių veiksnių (Sale, 1988; Komi, 1986; Aagaard, 2003).

Raumenu jègos ir masès didinimo metodiku îvairovė pagrịsta krūvio intensyvumo, trukmès ir dažnumo kaitaliojimu. Pradedantiesiems dažniausiai rekomenduojamos trejos pratybos per savaitę: per kiekvieną iš ju atliekama $6-10$ pratimu, 2-3 serijos po 8-12 kartojimų. Didelio meistriškumo kūno rengybos sportininkai atlieka $4-6$ pratybas, o kai kuriais atvejais net 8 -12 pratybu per savaite (dvejas pratybas per dieną skirtingoms raumenu grupėms ugdyti). Tokio tipo pratybomis (dažnais, bet palyginti mažos apimties krūviais) galima labiau padidinti mikrociklo (savaitès) krūvio intensyvumą. Manoma, kad didesnis intensyvumas labiau aktyvuoja nervinius ir hormoninius mechanizmus, todèl smarkiai didejja raumenu jèga ir masè (Kraemer et al., 1995; Green et al., 1998; Campos et al., 2002; Harber et al., 2004).

Pastebèta, kad raumenų masę pakankamai veiksmingai didina reti didelès apimties krūviai (Sale et al., 1990). Po tokių krūvių raumenų apimtis didèja dèl metabolinio stimulo aktyvavimo (Jones et al., 1989; Crewther et al., 2006). Kūno rengybos specialistai dažnai taiko 10 serijų metodiką: per šio tipo pratybas viena raumenų grupe treniruojama tiktai karta per savaitę, atliekant 10 serijų po 10 kartojimų. Nors 10 serijų metodika taikoma dažnai, jos veiksmingumas moksliniais eksperimentais mažai pagrisstas.

Tyrimo tikslas - nustatyti keturgalvio šlaunies raumens storio ir kojų raumenu jẻgos pokyti po septynių savaičių trukmès pratybų, kurių metu buvo taikomos skirtingos jègos lavinimo metodikos. Atliekant tyrimą kelta hipotezė: dažni mažos apimties jègos krūviai yra veiksmingesni nei reti didelès apimties krūviai, kadangi pastarieji, būdami ne tokie intensyvūs, mažiau aktyvuoja nervinius ir hormoninius mechanizmus, nuo kuriu ypač priklauso raumenu jëgos ir masès didejjimas (Green et al., 1998; Fry, 2004).

\section{TYRIMO METODIKA}

Tiriamieji. Buvo tiriama 14 fiziškai aktyvių vyrų, kurie turèdavo sportinių žaidimų pratybas 2-3 kartus per savaitę. Jų amžius - 23,3 $\pm 5,2 \mathrm{~m}$., ūgis $-181,7 \pm 5,1 \mathrm{~cm}$, svoris $-77,7$ $\pm 11,1 \mathrm{~kg}$. Prieš eksperimentą tiriamieji treniruokliu atliko spaudimo kojomis testą, po kurio pagal gautus rezultatus buvo suskirstyti tolygiai i dvi grupes: pirmą (E 1) eksperimentinę (atliko dažnus mažos apimties krūvius) ir antrą (E 2) eksperimentinę (atliko retus didelès apimties krūvius). Per paskutinius 6 mènesius tiriamieji nedare jègos lavinimo pratimų, savaitę prieš tyrimą ir jo metu papildomai nesportavo. Taip pat buvo susitarta, kad eksperimento metu tiriamieji išlaikys savo mitybos ipročius. Tyrimas atliktas laikantis $1975 \mathrm{~m}$. Helsinkio deklaracijoje priimtu principu dèl žmonių eksperimentų etikos.

Tyrimo protokolas. Prieš tyrimus tiriamieji buvo supažindinti su jègos matavimo procedūra ir atliko keletą bandymų. Svorio spaudimo kojomis treniruokliu testą jie atliko sporto klube „Idèja“. Po savaitès LKKA Žmogaus motorikos laboratorijoje išmatuotas keturgalvio šlaunies raumens storis ir nustatyta kojų raumenų izometrinè bei izokinetinè jèga. Testavimų eiga:

1. Tiriamujų kūno svoris, riebalų procentas ir kūno masès indeksas nustatyti kūno sudèties analizatoriumi „Tanita“ (Tanita Corporation, Japonija).

2. Dominuojančios kojos keturgalvio šlaunies raumens storis išmatuotas ultragarsine diagnostine sistema TITANTM (SonoSite, JAV).

3. Pramankšta: trukmè -8 min, galingumas $80 \mathrm{~W}$, veloergometro mynimo dažnumas 70 aps. / min (Ergo-fit 177, Vokietija).

4. Tiriamieji buvo sodinami i i izokinetinio dinamometro kẻdę, tvirtinami diržais. Testuota dominuojanti koja per kelio sąnari esant $70^{\circ}$ kampui $\left(0^{\circ}\right.$ - koja per kelio sąnarị visiškai ištiesta). Testavimo seka: 1) elektrostimuliacija $100 \mathrm{~Hz}$ (P 100) dažniu; 2) matuojama izometrinè maksimalioji valinga jèga (MVJ) - du bandymai (kiekvienas 2-3 s trukmès) darant $60 \mathrm{~s}$ pertrauka. Registruojamas bandymas, kurio metu pasiekiama didžiausia jèga.

5. Dominuojančios kojos koncentrinè jèga nustatyta tiesiant ir lenkiant blauzdą po 3 kartus $30^{\circ} / \mathrm{s}$ ir $300^{\circ} / \mathrm{s}$ greičiu. Tarp skirtingo greičio testavimu buvo daroma $60 \mathrm{~s}$ pertrauka. Registruojamas bandymas, kurio metu pasiekiama didžiausia jèga.

Tokia pačia seka testavimai atlikti po 7 savaičių pratybų programos. Kiekvieną savaitę tiriamieji turejjo po trejas pratybas. Abi eksperimentinès grupès vienodai treniravo visus kūno, išskyrus kojų, raumenis. E 1 tiriamieji atliko dažnus mažos apimties krūvius - kojomis spaudè svorị treniruokliu 3 kartus per savaitę po 3 (pirmadieniais, trečiadieniais) arba 4 serijas (penktadieniais) po 10 kartojimų. E 2 tiriamieji atliko retus didelès apimties krūvius - svorị spaudè treniruokliu vieną 
kartą per savaitę (trečiadieniais), 10 serijų po 10 kartojimu. Pertraukos tarp seriju -60 s. Atlikimo tempas 2-0-4 (2 s koncentrinè judesio fazè, $0 \mathrm{~s}$ sulaikymas, $4 \mathrm{~s}$ ekscentrine judesio fazè). Visus kitus pratimus tiriamieji atliko vidutiniu intensyvumu po 3-4 serijas ir po 6-12 pakartojimus.

Kojų raumenų jègos testavimas. Izometrinès ir izokinetinès jègos testavimui naudotas izokinetinis dinamometras (Biodex Medical System 3, New York). Tiriamieji buvo testuojami sèdintys, atlošo kampas $-90^{\circ}$. Norint sumažinti pečių, liemens ir šlaunies judesius, šios kūno dalys buvo apjuosiamos diržais. Blauzda tvirtinama diržu su sagtimi apatiniame trečdalyje, $4 \mathrm{~cm}$ virš kulnakaulio gumburo. Kelio anatomine sąnario ašis sulyginama su dinamometro dinaminès apkrovos mazgo ašimi atliekant valingą raumens susitraukimą 50\% intensyvumu. Elektrostimuliacijai atlikti ant keturgalvio šlaunies raumens distaliojo ir proksimaliojo trečdalio buvo dedami paviršiniai 9 x $12 \mathrm{~cm}$ elektrodai (PG912\x), turintys silikonini apvalkalą. Elektrodai sujungiami su elektrostimuliatoriumi, imontuotu $i$ elektromiografą „Medicor MG440“. Raumuo buvo dirginamas stačiakampès formos elektriniu impulsu arba jų serija. Vienkartinio impulso trukmè $-1 \mathrm{~ms}$, stimuliavimo trukmé - $1 \mathrm{~s}$. Stimuliavimo įtampa parinkta tokia, kad sukeltų didžiausią raumenų susitraukimo jègą $(150 \mathrm{~V})$. Elektrostimuliatoriaus siunčiamų dirgiklių (impulsų serijos) dažnis ir keturgalvio šlaunies raumens susitraukimo jèga buvo registruojama IBM tipo asmeniniu kompiuteriu, kuriuo valdomas ir elektrostatinio stimuliavimo režimas (CPU i486-33MHz, RAM 8M) Pulse Lab programa (programos kūrejas E. Pavilonis, 1994).

Maksimalioji kojų raumenų jèga buvo nustatoma spaudžiant svori horizontaliuoju svorio spaudimo kojomis treniruokliu (Motus, Pietų Korejja). Vengiant traumų taikyta metodika, pagrista kartojimais - iki tol, kol tiriamasis pavargdavo vienos serijos metu. Tiriamieji, pasirinkę pasipriešinimą turejjo atlikti kuo daugiau kartojimų. Jeigu tiriamasis atlikdavo 10 kartojimu, tai po 5 min testas buvo atliekamas iš naujo, padidinus pasipriešinimą. Pasipriešinimas buvo didinamas tol, kol tiriamasis nebegalėdavo pasiekti 10 kartojimu ribos. Maksimalioji jèga apskaičiuota pagal formulę (Brzycki,
1993): maksimalioji jèga, $\mathrm{kg}=$ pasipriešinimo dydis, $\mathrm{kg} /(1,0278-($ kartojimai $\times 0,0278))$.

Ultragarsinė diagnostika (echoskopija). U1tragarsiniai griaučių raumenų tyrimai atlikti naudojant ultragarsinę diagnostinę sistemą TITANTM ir ultragarsini $\mathrm{HST} / 10-5 \mathrm{MHz} 25 \mathrm{~mm}$ linijini davikli (SonoSite, JAV). Tyrimai atlikti tiriamajam gulint, atsipalaidavus. Keturgalvis šlaunies raumuo išmatuotas 5 taškuose. Taškai pasirinkti išvedus menamą linija tarp girnelès viršutinio krašto ir priekinio viršutinio klubikaulio dyglio kas $5 \mathrm{~cm}$, t. y. $5,10,15,20,25 \mathrm{~cm}$ nuo girnelès viršutinio krašto. Raumens storis vertintas pagal centimetrinès skalès reikšmes, matomas ekrane. Analizuojant rezultatus imtas visų penkių tašku vidurkis.

Duomenų statistinè analizè. Gauti rezultatai apdoroti matematinès statistikos metodais, skaičiuojant aritmetini vidurki $(\bar{x})$ ir standartini nuokrypi (S). Skirtumo tarp aritmetiniu vidurkiu reikšmingumas nustatytas pagal dvipusi priklausomų imčių, pasikartojamų matavimo Stjudento t (Student $t$ ) kriterijų. Aritmetinių vidurkių skirtumas buvo laikomas reikšmingu, jeigu $\mathrm{p}<0,05$.

\section{REZULTATAI}

Po septynių savaičių jègos krūvių tiriamujų svoris ir riebalų kiekis pakito nedaug (žr. lent.). Pirmoje eksperimentinèje grupèje dominuojančios tiriamuju kojos keturgalvio šlaunies raumens storis vidutiniškai padidejjo $10,6 \pm 9,5 \%(\mathrm{p}<0,05)$, antroje $-12,6 \pm 11,3 \%(\mathrm{p}<0,05)(1 \mathrm{pav}$.). Skirtumas tarp grupių rodikliu pagal raumens storio pokyti buvo statistiškai nereikšmingas ( $\mathrm{p}>$ 0,05). Eksperimento metu labiausiai padidèjo maksimalioji kojų raumenu jèga spaudžiant svori treniruokliu: $17,7 \pm 11,2 \%(\mathrm{p}<0,05)$ pirmoje ir $19,2 \pm 12,3 \%(\mathrm{p}<0,05)$ antroje grupeje $(\mathrm{p}>0,05$, lyginant $\mathrm{E} 1$ ir E 2 rodiklius) (2 pav.). Dominuojančios kojos izometrinè maksimalioji valinga ir $100 \mathrm{~Hz}$ elektrostimuliacijos sukelta jèga (3 pav.), izokinetinès koncentrinès jègos momentas (4 pav.) po septynių savaičių jẻgos krūvių, nepriklausomai nuo taikytos treniruočiu metodikos, statistiškai reikšmingai nepasikeitè.

\begin{tabular}{|l|c|c|c|c|}
\hline \multirow{2}{*}{ Rodikliai } & \multicolumn{2}{|c|}{$\begin{array}{c}\text { E 1 (dažni mažos apimties } \\
\text { krūviai) }\end{array}$} & \multicolumn{2}{c|}{$\begin{array}{c}\text { E 2 (reti didelès apimties } \\
\text { krūviai) }\end{array}$} \\
\cline { 2 - 5 } & Prieš & Po & Prieš & Po \\
\hline Kūno masė, $\mathrm{kg}$ & $78,3 \pm 8,4$ & $78,2 \pm 9,6$ & $77,2 \pm 13,2$ & $77,9 \pm 13,1$ \\
\hline KMI, kg / m ${ }^{2}$ & $23,8 \pm 2,6$ & $23,7 \pm 3,0$ & $23,3 \pm 3,7$ & $23,5 \pm 3,6$ \\
\hline Riebalų kiekis, \% & $15,3 \pm 4,3$ & $14,6 \pm 3,7$ & $14,5 \pm 6,0$ & $14,1 \pm 5,2$ \\
\hline
\end{tabular}
jègos krūvio $(\bar{x} \pm \mathrm{S})$ 
1 pav. Dominuojančios kojos keturgalvio šlaunies raumens storio pokytis po septynių savaičių skirtingų strategijų jègos krūvio $(\bar{x} \pm S)$

Pastaba. $*-p<0,05$, lyginant su reikšme prieš jègos pratybas.

2 pav. Kojụ raumenų jẻgos spaudžiant svorị treniruokliu pokytis po septynių savaičių skirtingų strategijų jègos krūvio $(\bar{x} \pm \mathbf{S})$

Pastaba. * $-\mathrm{p}<0,05$, lyginant su reikšme prieš jègos pratybas.

3 pav. Dominuojančios kojos izometrinès maksimaliosios valingos (MVJ) ir $100 \mathrm{~Hz}$ elektrostimuliacija sukeltos jègos (P 100) pokytis po septynių savaičių skirtingų strategijų jègos krūvio $(\bar{x} \pm S)$

4 pav. Dominuojančios kojos koncentrinès jègos, tiesiant ir lenkiant blauzdą 30 bei $300^{\circ}$ / s greičiu, pokytis po septynių savaičių skirtingų strategijų jẻgos krūvio ( $\bar{x} \pm \mathbf{S})$
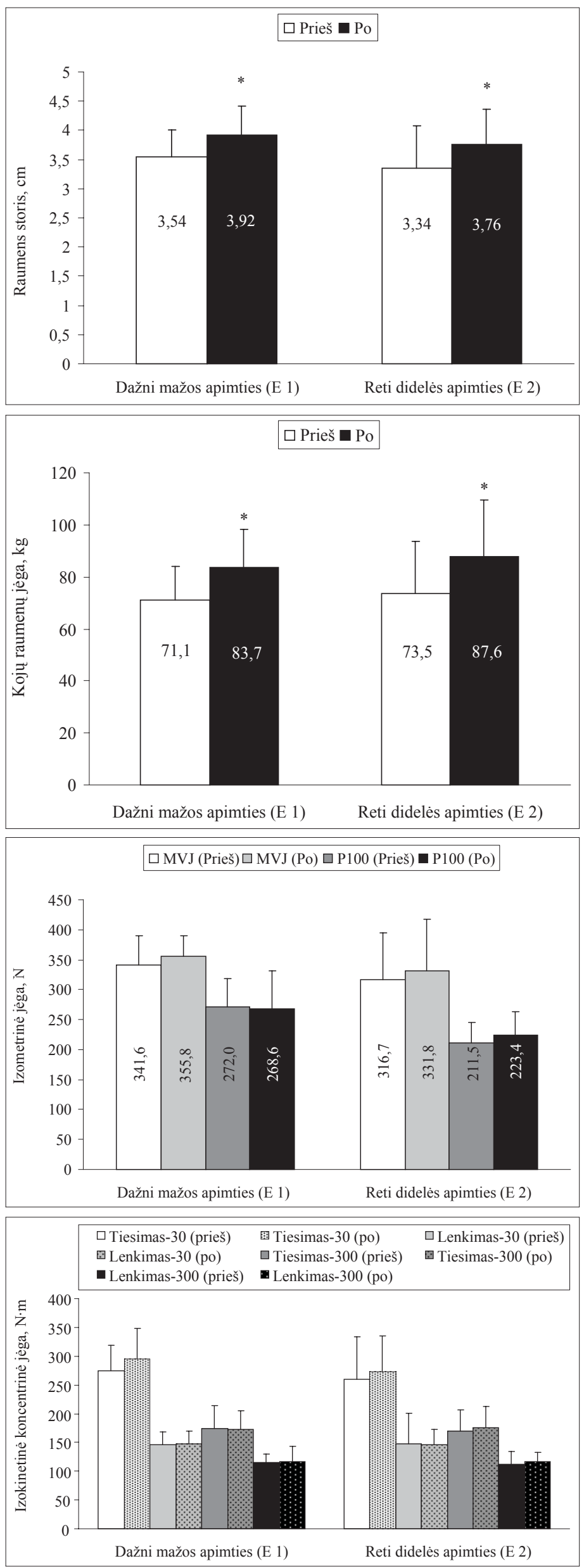


\section{REZULTATŲ APTARIMAS}

Tyrimo rezultatai parodè, kad motorinès sistemos adaptacija yra labai specifinè. Kojų jègos lavinimas svori spaudžiant treniruokliu labiau padidino keturgalvio šlaunies raumens storị ir maksimaliają kojų raumenu jẻgą, bet mažai keite izometrinio valingo ir elektrostimuliacijos sukelto raumens susitraukimo jègą bei izokinetinio raumens susitraukimo jègos momentą, esant skirtingam greičiui. Reti didelès apimties ir dažni mažos apimties krūviai sukèlè panašius adaptacinius motorinès sistemos pokyčius.

Tyrimas patvirtino, kad taikyti treniruotès metodai veiksmingai didina raumenu masę ir jègą. Po tokiu krūviu padidejja miofibrilių (baltymu, nuo kuriu priklauso raumenu susitraukimas) kiekis ir tankis (Fitts, Widrick, 1996; Narici et al., 1996; Kraemer, Ratamess, 2004), aktino, miozino, troponino, tropomiozino, miozino ATFazès, parvalbumino, Ca-ATFazès, kreatinfosfokinazès ir kt., vieno sarkomero baltymu kiekis (Jones et al., 1989). Manoma, kad del intensyviu pratybų krūvių gali padidèti net raumeninių skaidulų skaičius (raumeninių skaidulų hiperplazija) (Appell et al., 1988; Kadi, Thornell, 2000). Raumenų masè ypač greitai dideja per pirmąsias 9-12 savaičių: pastebètas $14 \%$ padidèjimas po 12 savaičių trukmès alkūnès lenkiamujų raumenų treniravimo (Roman et al., 1993), 12\% — po 9 savaičių trukmès keturgalvio šlaunies raumens treniravimo (Tracy et al., 1999) ir $10 \%$ - po 14 savaičių trukmès šlaunies raumenų treniravimo (Aagaard et al., 2000). Mūsų tyrimo metu keturgalvio šlaunies raumens storis treniruojantis vidutiniškai padidejo $11,6 \pm 10,2 \mathrm{~cm}$ per palyginti

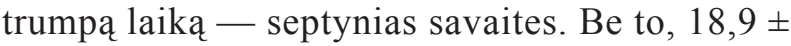
$11,8 \%$ padidejo kojų raumenu jèga spaudžiant svorį treniruokliu. Didelį ir greitą raumenų masès ir jègos prieaugi iš dalies paaiškina tai, kad buvo tiriami fiziškai aktyvūs, tačiau prie jẻgos krūviu neprisitaikę tiriamieji. Gerai žinoma, kad adaptacijos tempas priklauso nuo treniruotumo. Kuo mažesnis treniruotumas, tuo didesnis adaptacijos efektas (Häkkinen et al., 1989; Fleck, 1999). Didelio meistriškumo sportininkų raumenų masei ir jègai padidinti reikalingi santykiškai didesnès apimties ir intensyvesni fiziniai krūviai (Zatsiorsky, 1995).

Skirtingus mechanizmus aktyvuojančios raumenu masès didinimo metodika sukèlè labai panašius adaptacinius pokyčius. Taikant 10 serijų metodą labiau aktyvuojami metaboliniai mechanizmai. Šiam metodui būdingas santykiškai nedidelès apimties ir intensyvumo savaitinis krūvis, tačiau vieneriu pratybų krūvio apimtis ypač didelè. Pagrindiniai metaboliniai stimulai, skatinantys raumenu jègos didejjimą, yra ATF, kreatinfosfato (KF) išsekinimas ir metabolitų, atsirandančių skylant tokiems pagrindiniams energijos šaltiniams kaip neorganinio fosfato (Pi), adenozindifosforo rūgšties (ADF bei kreatino (K), padidejjimas (Zatsiorsky, 1995; Volek et al., 1999; Tesch, Alkner, 2003). Be to, po tokių krūviu padideja raumenų rūgšties kiekis ir sumažèja pH (Crewther et al., 2006). Kitos eksperimento metu taikytos treniravimo metodikos savaitinio ciklo apimtis buvo tokia pat kaip ir 10 serijų atveju, tik krūvis buvo atliekamas ne per vienerias, bet per trejas pratybas. Tai leido padidinti krūvio intensyvumą. Intensyvesnis krūvis labiau aktyvuoja hormoninius ir nervinius bei metabolinius mechanizmus. Manoma, kad tokie hormonai kaip insulinas, augimo hormonas, testosteronas ir ypač nuo insulino priklausantis augimo veiknys (IGF1 ir IGF-2), skatina baltymu sintezę ir kartu maksimaliosios raumenu jègos didejjimą (Kraemer et al., 1995; Crewther et al., 2006; Wackerhage, Ratkevičius, 2008. Visgi atlikto tyrimo rezultatai nepatvirtino hipotezès, kad intensyvesni krūviai bus veiksmingesni nei reti didelès apimties krūviai (10 serijų metodika). Tokius rezultatus galèjo lemti tiriamuju kontingentas. Prie jègos krūviú prisitaikę atletai lengviau pakelia didelio intensyvumo krūvị nei pradedantieji (Zatsiorsky, 1995), kuriems pradinio rengimo etapais bet kurios metodikos taikymas gali sukelti didelius adaptacinius pokyčius.

Tyrimo rezultatai parodè, kad kojų raumenų maksimalioji jẻga spaudžiant svorị treniruokliu (t. y. atliekant pratimą tokiomis pat sąlygomis kaip treniruojantis) padidejjo statistiškai reikšmingai, tačiau izometrinè valinga ir elektrostimuliacijos sukelta raumenu susitraukimo jèga bei izokinetinio raumenu susitraukimo jègos momentas pasikeitè nedaug. Tai susiję su krūvio specifiškumu - dinamine jèga tiesiogiai neperkeliama i izometrinę, ir atvirkščiai. Raumenu susitraukimo jègos prieaugis, ją lavinant valingai, ne visada pastebimas nevalingo elektrostimuliacijos sukelto raumenu susitraukimo metu. Kadangi sportininkų darbingumas priklauso nuo daugelio veiksnių, kiekvienam veiksniui ar jų sumai aktyvuoti reikia tam tikro fizinio krūvio (Sale, 1988; Skurvydas, 1998; Kraemer, Ratamess, 2004). Visiškai nestebina tai, kad atlikto tyrimo metu 
nepadidejo raumenų susitraukimo jėga esant skirtingam raumenų susitraukimo greičiui. Taip atsitiko del to, kad testavimo režimas ir greitis neatitiko treniravimo specifikos. Su labai dideliu pasipriešinimu išugdyta maksimalioji raumenu jèga gali trukdyti atlikti judesius dideliu greičiu (Skurvydas, 1998). Priklausomai nuo to, kokiu greičiu ir jèga raumuo susitraukinejja pratybu metu, prie tokiu jis labiau ir prisitaiko.

\section{IŠVADOS}

Reti didelès ir dažni mažos apimties septynių savaičių trukmès raumenų jègos lavinimo krūviai smarkiai padidino keturgalvio šlaunies raumens storį ir maksimaliają kojų raumenų jẻgą spaudžiant svori treniruokliu, tačiau mažai keitè izometrinę ir izokinetinę jègą. Taikant skirtingą jègos krūvio metodiką buvo aktyvuojami ne tie patys adaptacijos mechanizmai, tačiau jie sukèlè labai panašu adaptacijos efekta.

\section{LITERATŪRA}

Aagaard, P., Simonsen, E. B., Andersen, J. L. (2000). Neural inhibition during maximal eccentric and concentric quadriceps contraction: Effects of resistance training. Journal Applied of Physiology, 89 (6), 2249-57.

Aagaard, P. (2003). Training-induced changes in neural function. Exercise and Sport Science Reviews, 31, $61-67$.

Appell, H. J., Forsberg, S., Hollmann, W. (1988). Satellite cell activation in human skeletal muscle after training: Evidence for muscle fiber neoformation. International Journal of Sports Medicine, 9 (4), 297-9.

Bompa, T. O. (1999). Periodization: Theory and Methodology of training. Champaign, IL: Human Kinetics.

Brzycki, M. (1993). Strength testing: Predicting a one-rep max from reps-to-fatigue. JOHPERD 64, 88-90.

Campos, G. E. R., Luecke, T. J., Wendeln, H. K. et al. (2002). Muscular adaptations in response to three different resistance-training regiments: Specificity of repetition maximum training zones. Journal Applied of Physiology, 88, 50-60.

Crewther, B., Cronin, J., Keogh, J. (2006). Possible stimuli for strength and power adaptation: Acute metabolic responses. Sports Medicine, 36 (1), 65-78.

Crewther, B., Keogh, J., Cronin, J. et al. (2006). Possible stimuli for strength and power adaptation: Acute hormonal responses. Sports Medicine, 36 (3), 215-38.

Fitts, R. H., Widrick, J. J. (1996). Muscle mechanics: Adaptations with exercise-training. Exercise and Sport Sciences Reviews, 24, 427-473.

Fleck, S. J. (1999). Periodized strength training: A critical review. Journal of Strength Conditioning Research, 13 (1), 82-89.

Fry, A. C. (2004). The role of resistance exercise intensity on muscle fiber adaptations. Sports Medicine, 34 (10), $663-79$.

Green, H., Goreham, G., Ouyang, J. et al. (1998). Regulation of fiber size, oxidative potential, and capillarization in human muscle by resistance exercise. American Journal of Physiology, 276 (45), R 591-596.

Häkkinen, K. A., Pakarinen, P. V., Komi, T. et al. (1989). Neuromuscular adaptations and hormone balance in strength athletes, physically active males and females during intensity strength training. In R. J. Gregor, R. F. Zernicke, W. Whiting (Eds.), Proceedings of the XII International Congress of Biomechanics. (pp. 889-894) Champaign, IL: Human Kinetics..

Harber, M. P., Fry, A. C., Rubin, M. R. et al. (2004). Skeletal muscle and hormone adaptations to circuit weight training in untrained men. Scandinavian Journal of Medicine \& Science in Sports, 14 (3), 176-185.

Jennische, E., Skottner, A., Hansson, H. A. (1987). Satellite cells express the trophic factor IGF1 in regenerating skeletal muscle. Acta Physiologica Scandinavica, 129, 9-50.

Jones, D. A., Rutherford, O. M., Parker, D. F. (1989). Physiological changes in skeletal muscle as a result of strength training. Quarterly Journal of Experimental Physiology, 74, 233-256.

Kadi, F., Thornell, L. E. (2000). Concomitant increases in myonuclear and satellite cell content in female trapezius muscle following strength training. Histochemistry and Cell Biology, 113 (2), 99-103.

Komi, P. V. (1986). How important is neural drive for strength and power development in human skeletal muscle? In Biochemistry of Exercise VI (pp. 515-530). International Series on Sport Sciences, Vol. 16, ed. SALTIN, B. Champaign, IL, USA: Human Kinetics Publishers.

Kraemer, W. J., Aguilera, B. A., Terada, M. et al. (1995). Responses of IGF-I to endogenous increases in growth hormone after heavy-resistance exercise. Journal Applied of Physiology, 79 (4), 1310-1315.

Kraemer, W. J., Patton, J. F., Gordon, S. E. et al. (1995). Compatibility of high intensity strength and endurance training on hormone and skeletal muscle adaptations. Journal Applied of Physiology, 78, 976-989.

Kraemer, W. J., Ratamess, N. A. (2004). Fundamentals of resistance training: Progression and exercise prescription. Medicine and Science in Sports and Exercise, 36 (4), $674-688$.

Narici, M. V., Binzoni, T., Hiltbrand, E. et al. (1996). In vivo human gastrocnemius architecture with changing joint angle at rest and during graded isometric contraction. Journal of Physiology, 496 (1), 287-297.

Roman, W. J., Fleckenstein, J., Straygundersen, J. et al. (1993). Adaptations in the elbow flexors of elderly males after heavy-resistance training. Journal Applied of Physiology, 74, 750-4.

Sale, D. G., Jacobs, I., MacDougall, J. D. et al. (1990). Comparison of two regimens of concurrent strength and endurance training. Medicine and Science in Sports and Exercise, 22 (3), 348-356.

Sale, D. G. (1988). Neural adaptation to resistance training. Medicine and Science in Sports and Exercise, 20, 135-145.

Skurvydas, A. (1998). Judesiu valdymo ir sporto fiziologijos konspektai. Kaunas: LKKA.

Tesch, P. A., Alkner, B. A. (2003). Acute and chronic 
muscle metabolic adaptation to strenght training. In P. Komi (Ed.), Strenght and Power in Sports. (pp. 265-281) Blackwell Science Ltd.

Tracy, B. L., Ivey, F. M., Hurlbut, D. et al. (1999). Muscle quality. II. Effects of Strength training in 65- to 75-yearold men and women. Journal Applied of Physiology, 86 (1), 195-201.

Volek, J. S., Duncan, N. D., Mazzetti, S. A. et al. (1999).
Performance and muscle fiber adaptations to creatine supplementation and heavy resistance training. Medicine and Science in Sports and Exercise, 31 (8), 1147-1156.

Wackerhage, H., Ratkevičius, A. (2008). Signal transduction pathways that regulate muscle growth. Essays in Biochemistry, 44, 99-108.

Zatsiorsky, V. M. (1995). Science and Practise of Strength Training. Champaign, IL: Human kinetics.

\title{
LEG MUSCLE ADAPTATION AFTER RESISTANCE TRAINING LOADS WITH DIFFERENT STRATEGIES APPLIED
}

\author{
Sigitas Kamandulis ${ }^{1}$, Albertas Skurvydas ${ }^{1}$, Marius Brazaitis ${ }^{1}$, Daiva Imbrasiene ${ }^{1,2}$, Nerijus \\ Masiulis $^{1}$, Zita Andrijauskaitė ${ }^{1}$, Audrius Sniečkus ${ }^{1}$, Vidas Paleckis ${ }^{1}$, Darius Babickas ${ }^{3}$ \\ Lithuanian Academy of Physical Education ${ }^{1}$, Kaunas Ubniversity of Medicine ${ }^{2}$, \\ Sports Club „Idea" ${ }^{3}$, Kaunas, Lithuania
}

\begin{abstract}
Specialists of physical fitness often apply the so called method of 10 sets: one muscle group is trained only once a week performing 10 series of 10 repetition in each series. However, the efficiency of the 10 sets method has not been fully substantiated by scientific experiments. The aim of the present research was to establish the changes in quadriceps muscle thickness and leg muscle strength after seven weeks of resistance training applying different methods of strength development. We have hypothesized that frequent strength loads of low volume are more effective than rare loads of high volume as the latter ones, being less intensive, activate nervous and hormonal mechanisms less, and the increase in muscle strength and size greatly depends on those mechanisms.

The subjects of the research were 14 physically active men whose age was $23.3 \pm 5.2$ years, height $181.7 \pm 5.1 \mathrm{~cm}$, and weight $-77.7 \pm 11.1 \mathrm{~kg}$. Before the experiments the subjects performed a leg pressing test on the training machine after which they were divided into two groups according to the test results: the first experimental group (E 1 - frequent loads of low volume) and the second experimental group (E 2 - rare loads of high volume). The experiment lasted for 7 weeks. Every week the subjects had three practice sessions. Both experimental groups trained all the muscles of the body equally except for the leg muscles. The subjects in E 1 group performed leg pressing on the training machine three times a week: 3,3 and 4 series with 10 repetitions in each series. The subjects in E 2 group performed leg pressing on the training machine once a week: 10 series with 10 repetitions in each series. The measurements taken before and after the experiment: quadriceps muscle thickness by ultrasound, isometric maximal voluntary force and force induced by $100 \mathrm{~Hz}$ electro-stimulation at the angle of $70^{\circ}$ at the knee joint $\left(0^{\circ}\right.$ - full leg extension), isokinetic concentric force at the speed of 30 and $300^{\circ} / \mathrm{s}$, maximal leg muscle force performing force pressing on the training machine, body weight, percentage of body fat, and body mass index.

After seven weeks of resistance training the quadriceps muscle thickness in group $\mathrm{E} 1$ increased by $10.6 \pm$ $9.5 \%(p<0.05)$, in E 2 it increased by $12.6 \pm 11.3 \%(p<0.05)(p>0.05$, comparing E 1 and E 2$)$. In the course of the experiment the most prominent increase was observed in maximal leg muscle force while performing force pressing on the training machine: $17.7 \pm 11.2 \%(\mathrm{p}<0.05)$ in $\mathrm{E} 1$, and $19.2 \pm 12.3 \%(\mathrm{p}<0.05)$ in $\mathrm{E} 2(\mathrm{p}$ $>0.05$, comparing E 1 and E 2). However, maximal isometric voluntary force, force induced by $100 \mathrm{~Hz}$ electrostimulation and isokinetic concentric torque did not change statistically significantly irrespective of the strategies applied during resistance training.

Research results indicated that adaptation of motor system was highly specific. Infrequent loads of high volume and frequent loads of low volume developing leg muscle strength and lasting for seven weeks considerably improved quadriceps muscle thickness and maximal leg muscle force of pressing on the training machine, but they hardly changed isometric and isokinetic force. Methods of applying strength loads of different intensities activated not the same mechanisms, but they caused similar adaptation effect.
\end{abstract}

Keywords: 10 sets method, quadriceps muscle thickness, isometric force, isokinetic force, electrostimulation.

Gauta 2009 m. lapkričio 8 d.

Received on November 8, 2009

Priimta $2010 \mathrm{~m}$. vasario $4 \mathrm{~d}$.

Accepted on February 4, 2010
Dr. Sigitas Kamandulis

Lietuvos kūno kultūros akademija

(Lithuanian Academy od Physical Education)

Sporto g. 6, LT-44221 Kaunas

Lietuva (Lithuania)

Tel +37060073021

E-mails.kamandulis@1kka.1t 